\title{
Corrigendum: The role of dopamine in schizophrenia from a neurobiological and evolutionary perspective: old fashioned, but still in vogue
}

\section{Ralf Brisch ${ }^{*}$, Arthur Saniotis ${ }^{2,3}$, Rainer Wolf ${ }^{4}$, Hendrik Bielau ${ }^{5}$, Hans-Gert Bernstein ${ }^{5}$, Johann Steiner ${ }^{5}$, Bernhard Bogerts ${ }^{5}$, Katharina Braun ${ }^{6}$, Zbigniew Jankowski ${ }^{1}$, Jaliya Kumaratilake ${ }^{7}$, Maciej Henneberg ${ }^{7}$ and Tomasz Gos ${ }^{1}$}

1 Department of Forensic Medicine, Medical University of Gdańsk, Gdańsk, Poland

2 School of Medical Sciences, The University of Adelaide, Adelaide, SA, Australia

${ }^{3}$ Centre for Evolutionary Medicine, University of Zurich, Zurich, Switzerland

${ }^{4}$ Department of Psychiatry and Psychotherapy, Ruhr University Bochum, Bochum, Germany

${ }^{5}$ Department of Psychiatry, Otto-von-Guericke-University of Magdeburg, Magdeburg, Germany

${ }^{6}$ Department of Zoology/Developmental Neurobiology, Institute of Biology, Otto-von-Guericke-University of Magdeburg, Magdeburg, Germany

${ }^{7}$ Biological Anthropology and Comparative Anatomy Research Unit, School of Medical Sciences, The University of Adelaide, Adelaide, SA, Australia

*Correspondence: ralfbrisch@hotmail.com

Edited and reviewed by:

Thomas W. Weickert, University of New South Wales, Australia

Keywords: dopamine, schizophrenia, cognition, glutamate, dopamine receptors, cannabis, animal models of schizophrenia, evolution of the human brain

\section{A corrigendum on}

The role of dopamine in schizophrenia from a neurobiological and evolutionary perspective: old fashioned, but still in vogue

by Brisch $R$, Saniotis A, Wolf R, Bielau $H$, Bernstein H-G, Steiner J, Bogerts B, Braun $K$, Jankowski Z, Kumaratilake J, Henneberg M, Gos T. Front Psychiatry (2014) 5:47. doi:10.3389/fpsyt.2014.00047

The author Jaliya Kumaratilake's name was misspelled and the author Katharina Braun's name was wrongly displayed in the review "The role of dopamine in schizophrenia from a neurobiological and evolutionary perspective: old fashioned, but still in vogue". The correct citation for the review should be as follows:

Brisch R, Saniotis A, Wolf R, Bielau H, Bernstein H-G, Steiner J, Bogerts B, Braun K, Jankowski Z, Kumaratilake J, Henneberg M, Gos T (2014) The role of dopamine in schizophrenia from a neurobiological and evolutionary perspective: old fashioned, but still in vogue. Front Psychiatry 5:47. doi:10.3389/fpsyt.2014.00047.

The original article has been updated.

Conflict of Interest Statement: The authors declare that the research was conducted in the absence of any commercial or financial relationships that could be construed as a potential conflict of interest.

Received: 06 August 2014; accepted: 08 August 2014; published online: 27 August 2014.
Citation: Brisch R, Saniotis A, Wolf R, Bielau $H$, Bernstein $H-G$, Steiner J, Bogerts B, Braun $K$, Jankowski Z, Kumaratilake J, Henneberg $M$ and Gos $T$ (2014) Corrigendum: The role of dopamine in schizophrenia from a neurobiological and evolutionary perspective: old fashioned, but still in vogue. Front. Psychiatry 5:110. doi:10.3389/fpsyt.2014. 00110

This article was submitted to Schizophrenia, a section of the journal Frontiers in Psychiatry.

Copyright (๑) 2014 Brisch, Saniotis, Wolf, Bielau, Bernstein, Steiner, Bogerts, Braun, Jankowski, Kumaratilake, Henneberg and Gos. This is an open-access article distributed under the terms of the Creative Commons Attribution License (CC BY). The use, distribution or reproduction in other forums is permitted, provided the original author(s) or licensor are credited and that the original publication in this journal is cited, in accordance with accepted academic practice. No use, distribution or reproduction is permitted which does not comply with these terms. 